Vol 4. No 2. Agustus 2020

ISSN 2580-5029

\title{
Penggunaan Ruang Terbuka Hijau di Hotel Bintang Lima di Yogyakarta Sebagai Habitat Burung
}

\author{
Bambang Agus Suripto ${ }^{*}$, Rista Tamara ${ }^{2}$ \\ 1,2 Fakultas Biologi, Universitas Gadjah Mada, D.I.Yogyakarta, Indonesia \\ *Email : suriptobambang@yahoo.com
}

\begin{abstract}
The presence of green open space in a city plays an important role in ecological functions, one of which has the potential to become a birds habitat. Plant composition in GOS plays an important role in the use of habitat by birds. Studies on the presence of GOS as birds habitat are still growing. In this study, the use of GOS in five-star hotels in Yogyakarta as birds habitat is examined. The study was conducted in February-March and June 2020 at the GOS of Royal Ambarrukmo Hotel, Sheraton Mustika Resort \& Spa, and the edge of the Hyatt Regency Yogyakarta property. The method used is IPA, birds identification using Mac Kinnon's guidebook, and taking vegetation data using the quadratic plot method. Based on research, total of birds species that were found are 22 species from 14 families. Plant species were found are 59 species from 33 families. Based on research found that the more diverse types of plants in a habitat, the more diverse species of birds found. The composition of birds is dominated by graminivorous groups. The use of GOS in the three hotels acts as a bird habitat to support all its activities including foraging, perching, and nesting.
\end{abstract}

Keywords: bird, habitat, diversity, GOS, hotel, five-star.

\begin{abstract}
ABSTRAK
Keberadaan ruang terbuka hijau di suatu kota berperan penting dalam fungsi ekologis, salah satunya berpotensi menjadi habitat berbagai jenis satwa termasuk burung. Komposisi tumbuhan di RTH memainkan peranan penting dalam pemanfaatan habitat oleh burung. Kajian mengenai keberadaan RTH sebagai habitat burung masih terus berkembang. Pada penelitian ini dikaji mengenai penggunaan RTH pada hotel berbintang lima di Yogyakarta sebagai habitat burung. Penelitian dilakukan pada bulan Februari-Maret dan Juni 2020 di RTH yang ada di Royal Ambarrukmo Hotel, Sheraton Mustika Resort \& Spa, dan tepian properti Hyatt Regency Yogyakarta. Metode yang digunakan yaitu IPA (Index Point of Abundance), identifikasi burung menggunakan buku panduan Mac Kinnon (2010), serta dilakukan pengambilan data vegetasi dengan metode plot kuadrat. Berdasarkan penelitian, jenis burung yang ditemukan sebanyak 22 spesies dari 14 famili. Jenis tumbuhan yang ditemukan sebanyak 59 spesies dari 33 famili. Berdasarkan penelitian didapatkan bahwa, semakin beragam jenis tumbuhan pada suatu habitat, maka semakin beragam pula jenis burung yang ditemukan. Komposisi burung didominasi oleh kelompok graminovorous. Penggunaan RTH di ketiga hotel berperan sebagai habitat burung untuk mendukung segala aktivitasnya diantaranya mencari makan, bertengger dan bersarang.
\end{abstract}

Kata Kunci: burung, habitat, keragaman, RTH, hotel, bintang-lima. 


\section{PENDAHULUAN}

Ruang terbuka hijau (RTH) merupakan suatu area yang lantainya secara menyeluruh maupun sebagian ditutupi oleh rerumputan, dan ditumbuhi berbagai macam jenis vegetasi, seperti pepohonan dan semak. Berdasarkan UU RI Nomor 26 Tahun 2007 Tentang Penataan Ruang, RTH adalah area yang memanjang atau mengelompok, yang penggunaannya lebih bersifat terbuka, sebagai tempat tumbuh tanaman, baik yang tumbuh secara alamiah maupun yang sengaja ditanam. Keberadaan ruang terbuka hijau (RTH) pada suatu kota memiliki peran yang sangat penting dalam kehidupan bermasyarakat, serta ikut menjaga kelestarian flora dan fauna didalamnya, termasuk berbagai jenis burung. Kota Yogyakarta merupakan salah satu kota yang mengalami peningkatan pesat terutama dalam pembangunan infrasutrukturnya. Keberadaan RTH perlu menjadi perhatian utama dalam pengelolaan serta perencanaan pembangunan dan tata letak di Yogyakarta. Salah satu implementasinya yaitu penyediaan lahan untuk RTH yang dilakukan di beberapa hotel berbintang lima di Yogyakarta. Berdasarkan jenisnya, RTH pada hotel bintang lima termasuk dalam ruang terbuka hijau privat, yaitu RTH yang dimiliki dan dikelola oleh institusi ataupun perseorangan yang pemanfaatannya untuk kalangan terbatas (Ratnasari dkk, 2015). RTH di hotel berbintang lima umumnya di isi dengan kawasan taman yang bersifat formal dan dekoratif. Taman didominasi dengan pepohonan hijau yang ditata sebagai elemen pembentuk ruang dan keteduhan. RTH yang tersedia di hotel bintang lima selain memberikan bentuk keindahan dan kesegaran bagi pengunjung, secara tidak langsung juga berperan dalam pelestarian lingkungan, salah satunya berpotensi sebagai habitat berbagai jenis burung.

Komposisi tumbuhan di RTH memainkan peran penting dalam pemanfaatan habitat oleh burung. Perbedaan komposisi pepohonan dapat mempengaruhi seleksi habitat dan struktur komunitas burung. Kekayaan jenis vegetasi penyusun suatu habitat dapat memberikan pengaruh positif terhadap diversitas burung (Gabbel et al., 2002; Rodewald \& Abrams, 2002; Salek et al., 2010). Struktur vegetasi seperti pepohonan dan semak yang banyak dijumpai di RTH, berperan dalam menyediakan sumber makanan, tempat untuk mencari makan, bersarang maupun bertengger. Suatu habitat dengan struktur pepohonan yang rapat, dapat memberikan perlindungan terhadap burung dari ancaman predator dan kondisi cuaca yang ektrim (Silva et al., 1996; Estrada et al., 1997; Luck \& Daily, 2003; Harvey et al., 2006). Keberagaman struktur vegetasi dan jenis tumbuhan didalamnya, maka akan mempengaruhi keberagaman jenis burung yang dijumpai.

RTH pada suatu perkotaan menjadi fragmen habitat dari ekosistem yang beragam, hal tersebut mempengaruhi keanekaragaman 
jenis burung yang hidup didalamnya. RTH pada perkotaan menghasilkan habitat yang sederhana dan komunitas burung non-native akan lebih sedikit dijumpai (Schaefer, 1994; Marzluff et al., 1998). Berbagai burung native dapat mengatasi adanya perubahan habitat alaminya dan bahkan beberapa dapat hidup lebih makmur dibandingkan hidup di habitat alaminya. Beberapa desain perkebunan dan pertamanan di RTH ditumbuhi pepohonan tinggi yang serupa dengan habitat alaminya, serta ditumbuhi pula tanaman eksotik yang menghasilkan berbagai macam hasil seperti biji dan buah-buahan yang menyediakan sumber pakan ideal bagi beberapa burung. Namun terdapat pula yang gagal menyediakan struktur vegetasi yang dibutuhkan bagi beberapa jenis burung. Habitat perkotaan menawarkan sumber pakan dan tempat perlindungan, tetapi tidak selalu sesuai bagi beberapa jenis burung.

Keberadaan RTH di Kota Yogyakarta dan taman-taman publik maupun privat lainnya memiliki potensi sebagai habitat burung. Kajian mengenai keberadaan RTH di Yogyakarta sebagai habitat burung masih terus berkembang. Pada penelitian ini bertujuan untuk mengetahui penggunaan RTH di hotel berbintang lima sebagai habitat burung. Hal tersebut dapat diketahui melalui keanekaragaman jenis burung yang ditemui beserta aktivitasnya, dan hubungannya dengan keanekaragaman vegetasi yang ada didalamnya. Penelitian ini diharapkan dapat menjadi masukan bagi pemerintah kota/daerah dalam mengelola dan merencanakan pembangunan khususnya di Kota Yogyakarta, dalam mempertimbangkan keberadaan RTH baik publik maupun privat sebagai salah satu upaya konservasi burung.

\section{METODE}

\section{Tempat dan waktu penelitian}

Penelitian dilakukan di RTH yang terdapat di tiga Hotel Bintang Lima di Yogyakarta yaitu Royal Ambarurrukmo Yogyakarta Hotel, Sheraton Mustika Yogyakarta Resort \& Spa, dan tepian properti Hyatt Regency Yogyakarta. Pengambilan data dilakukan pada bulan Februari hingga Maret 2020. Pengamatan dilakukan pada pukul 06.00 - 10.00 di pagi hari dan pada pukul 16.00-17.30 di sore hari, dilakukan selama lima hari hari berturut-turut pada setiap hotel.

\section{Bahan dan alat}

Alat yang digunakan pada penelitian ini adalah alat tulis, teropong binocular 10x70x70, kamera mirrorless, lensa tele 50$230 \mathrm{~mm}$, jam tangan digital, dan meteran laser digital. Bahan yang digunakan diantaranya berupa kertas label dan peta topografi lokasi.

\section{Metode}

\section{Identifikasi Burung}

Pengambilan data burung dilakukan dengan metode IPA (Indices Ponctue;s d'Abondence). Tahapan yang dilakukan, diawali dengan menentukan lokasi sampling di RTH pada ketiga hotel. Lokasi sampling tersebut berupa titik-titik sampling (TS) yang merupakan nomor-nomor IPA. Pengamat berdiri pada tiap TS dengan luasan tertentu, dan mencatat segala jenis burung yang 
dijumpai maupun didengar beserta jumah individu tiap jenisnya selama 15 menit. Digunakan 22 titik sampling pada setiap hotel, dengan diameter pada tiap TS sebesar 10 meter, luas area dihitung dengan menggunakan rumus luas lingkaran. Jenis burung yang dijumpai dicatat segala aktivitas yang dilakukan, dan dilakukan identifikasi dengan menggunakan Buku Panduan Lapangan Burung Di Sumatera, Jawa, Bali dan Kalimantan (MacKinnon et al., 2010). Penelitian ini dilaksanakan pada pagi hari yaitu pukul 06.00-11.00 dan dilanjutkan pada sore hari pukul 15.00 - 17.30 setiap harinya. Penelitian dilanjutkan pada empat hari berikutnya dengan batas waktu yang sama untuk setiap hotel.

2. Tabulasi pengambilan data vegetasi

Pengambilan data vegetasi pohon dilakukan dengan metode kuadrat plot. Metode ini menggunakan plot berbentuk bujur sangkar dengan ukuran $10 \mathrm{~m}$ x $10 \mathrm{~m}$ yang diletakkan pada titik sampling ketika mendapatkan data keanekaragaman jenis burung. Kemudian dilakukan pencatatan jenis pepohonan yang ditemui pada tiap TS dan dilakukan identifikasi dengan buku panduan flora of java . Kemudian diamati pula jenis pepohonan yang menjadi tempat singgah bagi burung untuk bertengger maupun bersarang.

\section{Analisis data}

\section{Keragaman burung dan vegetasi.}

Data yang diperoleh selama pengamatan, berupa jumlah individu dari setiap jenis burung dan vegetasi maupun total dari seluruh jenisnya, digunakan untuk menghitung indeks diversitas Shannon Wiener. Indeks ini digunakan sebagai ukuran yang menunjukkan proporsi kelimpahan masing-masing jenis di suatu habitat.

$$
\begin{aligned}
& H^{\prime}=-\sum P i \ln (P i) \\
& H^{\prime}=\text { Indeks Shannon Wiener } \\
& \mathrm{Pi}=\text { Proporsi individu jenis ke-I } \\
& \text { terhadap semua jenis }(\mathrm{Pi}=\mathrm{ni} / \mathrm{N}) \\
& \mathrm{Ln}=\text { Logaritma natural } \\
& \mathrm{Ni}=\text { Jumlah Individu spesies ke-i } \\
& \mathrm{N}=\text { Total Individu Semua Spesies }
\end{aligned}
$$

Tingkat keanekaragaman dianalisis berdasaran kriteria Lee et al., (1987) dalam Soegianto (1994), yaitu :

$\begin{array}{ll}\text { Tinggi } & >2,0 \\ \text { Sedang } & \leq 2,0 \\ \text { Rendah } & <1,6 \\ \text { Sangat rendah } & <1,0\end{array}$

\section{Keberadaan Jenis-jenis burung yang dilindungi}

Status Perlindungan jenis burung ditentukan berdasarkan Peraturan Menteri Lingkungan Hidup dan Kehutanan Republik Indonesia Nomor P.106/MENLHK/SETJEN/KUM.1/12/2018 tentang Jenis Tumbuhan dan Satwa yang Dilindungi, dan status keterancaman berdasarkan IUCN redlist.

\section{Komposisi Jenis Pakan}

Untuk mengetahui jenis pakan dari burung yang telah di temukan, menggunakan buku Mac Kinnon, serta dihitung dengan 
menggunakan indeks nilai penting. Indeks nilai penting adalah penjumlahan dari nilainilai kerapatan relatif, frekuensi relatif dan densitas relatif :

$$
I N P=F R+D R
$$

INP = Indeks nilai penting

$\mathrm{FR}=$ Frekuensi relatif

$\mathrm{DR}=$ Densitas relative

\section{HASIL DAN PEMBAHASAN}

\section{Keanekaragaman jenis burung}

Berdasarkan hasil pengamatan jenis burung yang ditemukan di RTH ketiga hotel berbintang lima yaitu sebanyak 22 spesies dari 14 famili. Jenis burung yang paling umum dijumpai pada ketiga lokasi adalah anggota burung bondol jawa (Lonchura leucogastroides) dan burung gereja (Passer montanus). Menurut Tobolka (2011), burung gereja memiliki tingkat adaptasi yang tinggi pada lingkungan manapun, mereka juga tahan terhadap perubahan kondisi cuaca, ketersediaan pakan maupun predator. Burung gereja memiliki kemampuan berkoloni dan tidak takut akan kehadiran manusia. Oleh sebab itu, burung ini juga dapa dijumpai dilahan yang padat penduduk. Bondol jawa juga dapat dengan mudah beradaptasi pada berbagai macam tipe habitat, terlihat dalam kemampuannya berkembangbiak. Berdasarkan penelitian Sharma et al., (2004), disebutkan bahwa tingkat keberhasilan bondol jawa untuk berkembang biak mampu mencapai $48,7 \%$ dihabitat perkotaaan dan $31,6 \%$ di habitat aslinya.

Tabel 1. Jenis burung yang dijumpai di RTH Royal Ambarrukmo, Sheraton Mustika dan tepian properti Hyatt Regency Yogyakarta.

\begin{tabular}{|c|c|c|c|c|c|c|}
\hline \multirow[t]{2}{*}{ No. } & \multicolumn{3}{|c|}{ Jenis Burung } & \multicolumn{3}{|c|}{ Keberadaan } \\
\hline & Nama Lokal & Nama Ilmiah & Famili & $\mathbf{R A}$ & SM & HR \\
\hline 1. & Bondol jawa & $\begin{array}{l}\text { Lonchura leucogastroides (Moore, } \\
1858 \text { ) }\end{array}$ & & $\sqrt{ }$ & $\sqrt{ }$ & $\sqrt{ }$ \\
\hline 2. & Bondol haji & Lonchura maja (Linnaeus, 1766) & Estrildidae & $\sqrt{ }$ & $\sqrt{ }$ & - \\
\hline 3. & Bondol peking & $\begin{array}{l}\text { Lonchura punctulata (Linnaeus, } \\
1758 \text { ) }\end{array}$ & & $\sqrt{ }$ & $\sqrt{ }$ & $\sqrt{ }$ \\
\hline 4. & $\begin{array}{l}\text { Burung gereja } \\
\text { erasia }\end{array}$ & $\begin{array}{l}\text { Passer Montanus (Linnaeus, } \\
1758 \text { ) }\end{array}$ & Passeridae & $\sqrt{ }$ & $\sqrt{ }$ & $\sqrt{ }$ \\
\hline 5. & Cucak kutilang & $\begin{array}{l}\text { Pycnonotus aurigaster (Vieillot, } \\
1818 \text { ) }\end{array}$ & & $\sqrt{ }$ & $\sqrt{ }$ & - \\
\hline 6. & Merbah cerukcuk & $\begin{array}{l}\text { Pycnonotus goiavier (Scopoli, } \\
1786 \text { ) }\end{array}$ & Pycnonotidae & $\sqrt{ }$ & $\sqrt{ }$ & $\sqrt{ }$ \\
\hline 7. & Layang-layang api & Hirundo rustica (Linnaeus, 1758) & & $\sqrt{ }$ & - & - \\
\hline 8. & $\begin{array}{l}\text { Layang-layang } \\
\text { loreng }\end{array}$ & $\begin{array}{l}\text { Cecropis striolata (Schlegel, } \\
1844 \text { ) }\end{array}$ & Hirundinidae & - & $\sqrt{ }$ & - \\
\hline 9. & Cabai jawa & $\begin{array}{l}\text { Dicaeum trochileum (Sparman, } \\
1789 \text { ) }\end{array}$ & Dicaeidae & $\sqrt{ }$ & - & $\sqrt{ }$ \\
\hline 10. & Kerak kerbau & $\begin{array}{l}\text { Acridotheres javanicus (Cabanis, } \\
\text { 1851) }\end{array}$ & Sturnidae & $\sqrt{ }$ & - & - \\
\hline 11. & Jalak cina & Agropsar sturninus (Pallas, 1776) & & $\sqrt{ }$ & - & - \\
\hline 12. & Kekep babi & $\begin{array}{l}\text { Artamus leucoryn (Linnaeus, } \\
\text { 1771) }\end{array}$ & Artamidae & $\sqrt{ }$ & - & - \\
\hline
\end{tabular}


Biotropic Tahun 2020, Vol.4 (N0. 2): 119 - 133

Penggunaan Ruang Terbuka Hijau di Hotel Bintang Lima di Yogyakarta Sebagai Habitat Burung

\begin{tabular}{|c|c|c|c|c|c|c|}
\hline \multirow[t]{2}{*}{ No. } & \multicolumn{3}{|c|}{ Jenis Burung } & \multicolumn{3}{|c|}{ Keberadaan } \\
\hline & Nama Lokal & Nama Ilmiah & Famili & $\mathbf{R A}$ & $\mathbf{S M}$ & HR \\
\hline 13. & Kipasan belang & $\begin{array}{l}\text { Rhipidura javanica (Sparman, } \\
\text { 1788) }\end{array}$ & Rhipiduridae & $\sqrt{ }$ & - & - \\
\hline 14. & $\begin{array}{l}\text { Burung madu } \\
\text { sriganti }\end{array}$ & $\begin{array}{l}\text { Cinnyris jugularis (Linnaeus, } \\
1766 \text { ) }\end{array}$ & Nectariniidae & $\sqrt{ }$ & - & - \\
\hline 15. & Cipoh kacat & Aegithina tiphia (Linnaeus, 1758) & Aegithinidae & - & $\sqrt{ }$ & - \\
\hline 16. & Perkutut ketitir & Geopelia Striata (Linnaeus, 1766) & & $\sqrt{ }$ & $\sqrt{ }$ & - \\
\hline 17. & Punai gading & Treron vernans (Linnaeus, 1771) & & $\sqrt{ }$ & $\sqrt{ }$ & - \\
\hline 18. & Tekukur biasa & $\begin{array}{l}\text { Streptopelia chinensis (Scopoli, } \\
\text { 1786) }\end{array}$ & Columbidae & - & $\sqrt{ }$ & - \\
\hline 19. & Merpati & Columba livia (Gmelin, 1786) & & - & - & $\sqrt{ }$ \\
\hline 20. & Walet linci & $\begin{array}{l}\text { Collocalia linchi (Horsfield \& } \\
\text { Moore, 1854) }\end{array}$ & Apodidae & $\sqrt{ }$ & - & - \\
\hline 21. & $\begin{array}{l}\text { Takur ungkut- } \\
\text { ungkut }\end{array}$ & $\begin{array}{l}\text { Megalaima haemacephala (Statius } \\
\text { Muller, 1766) }\end{array}$ & Ramphastidae & - & $\sqrt{ }$ & - \\
\hline 22. & Cekakak sungai & $\begin{array}{l}\text { Todirhamphus chloris (Boddaert, } \\
\text { 1783) }\end{array}$ & Alcedinidae & - & - & $\sqrt{ }$ \\
\hline
\end{tabular}

Keterangan : RA (RTH Royal Ambarrukmo), SM (RTH Sheraton Mustika), HR (RTH tepian properti Hyatt Regency Yogyakarta).

Berdasarkan gambar 1, menurut

Berdasarkan Tabel 1., jenis burung yang ditemukan di RTH ketiga hotel berbintang lima yaitu sebanyak 22 spesies dari 14 famili. Jenis burung yang paling umum dijumpai pada ketiga lokasi adalah burung bondol jawa (Lonchura leucogastroides) dan burung gereja (Passer montanus).

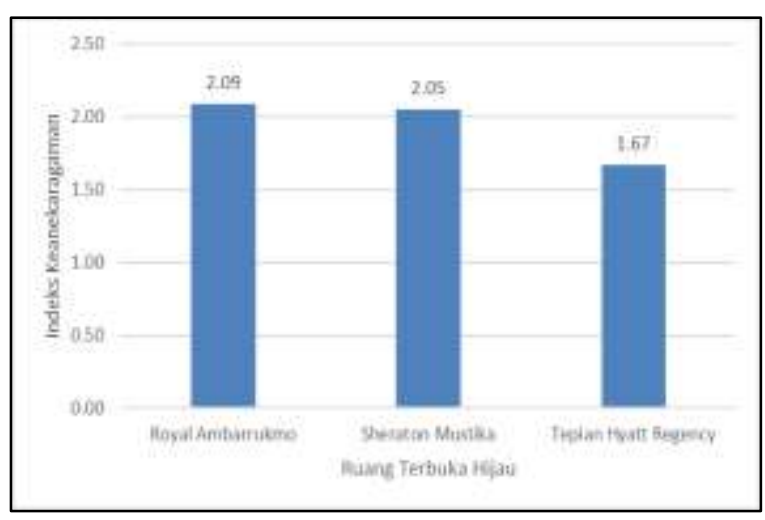

Gambar 1. Indeks keanekaragaman burung di RTH Royal Ambarrukmo, Sheraton Mustika dan tepian properti Hyatt Regency Yogyakarta. kriteria Lee et al., (1978) dalam Soeogianto (1994) keanekaragaman burung di RTH yang ada di Royal Ambarrukmo dan Sheraton Mustika termasuk dalam tingkat yang tinggi $\left(H^{\prime}>2,0\right)$. Sedangkan tingkat keanekaragaman pada RTH di tepian properti Hyatt Regency Yoyakarta berada pada tingkatan yang sedang $(\mathrm{H} \leq 2,0)$.

Berdasarkan hasil yang diperoleh, RTH yang berada di Hotel Royal Ambarrukmo memiliki indeks keragaman jenis burung tertinggi. Semakin besar nilai indeks, maka semakin beragam pula jenis burung dan jumlah individunya pun semakin merata. Tingginya nilai keanekaragaman burung di RTH Royal Ambarrukmo dapat disebabkan karena pada habitat tersebut tersedia sumber pakan yang melimpah, didukung oleh keberadaan vegetasi yang lebih rimbun dan banyak, yang sesuai sebagai tempat untuk berlindung, bersarang maupun bertengger bagi beberapa jenis burung. Campos et al., 
(2009) menyatakan bahwa keberadaan vegetasi pada suatu habitat memiliki peran sebagai sumber pakan, tempat berlindung dan sebagai lokasi bersarang. Hal tersebut juga berlaku bagi keanekaragaman jenis burung yang berada di RTH Sheraton Mustika yang tidak terlalu berbeda jauh dengan RTH Royal Ambarrukmo. Indeks keanekaragaman jenis burung yang lebih rendah dapat disebabkan karena struktur vegetasi yang tidak lebih rapat dari RTH Royal Ambarrukmo. Namun, RTH Sheraton Mustika mampu untuk memberikan habitat bagi burung, dibuktikan dengan indeks keanekaragaman burung yang tergolong tinggi.

Sedangkan RTH di tepian properti Hyatt Regency memiliki tingkat keanekaragaman yang sedang. Hal tersebut dapat disebabkan karena lokasi tersebut berdekatan dengan jalan raya yang dipenuhi dengan lalu lalang kendaraan. Paparan kebisingan yang terus menerus dapat mempengaruhi keberadaan burung pada suatu habitat. Frekuensi kebisingan yang dihasilkan oleh kendaraan bermotor akan bertabrakan dengan frekuensi suara yang dihasilkan oleh burung. Bunyi antropogenik yang terus menerus ini dapat menggangu struktur social hewan, salah satunya mengganggu komunikasi akustik yang sangat vital bagi burung baik untuk menemukan pasangan, menjaga daerah territorial dan berburu (Halfwerk et al., 2011: Cartwright et al., 2014; Catchpole\&Slater, 2003). Namun, beberapa jenis burung memiliki toleransi terhadap kebisingan, seperti pada jenis burung urban-tolerant. Jenis burung tersebut cenderung bertubuh kecil dan memiliki sinyal frekuensi yang lebih tinggi sehingga menerima sedikit gangguan akustik dari kebisingan daripada burung yang bersuara dengan frekuensi yang lebih rendah. Burung urban-tolerant memiliki toleransi lingkungan yang lebih luas, selain itu keberadaan mereka juga didukung oleh tersedianya peluang untuk mencari makan dan bersarang (Hu \& Cardoso, 2009; Bonier et al., 2007; Croci et al., 2008). RTH di tepian properti Hyatt regency Yogyakarta dikenal dengan pohon perindang jalan yang berderetan dan cukup rimbun. Kawasan tersebut mampu menyediakan sumber pakan dan menjadi tempat bertengger yang aman bagi beberapa jenis burung.

\section{Status Konservasi Jenis Burung}

Terdapat satu jenis burung yang dijumpai di lokasi penelitian yang bersatus dilindungi berdasarkan PERMENLHK No.P.20/MENLHK/SETJEN/KUM.1/12/2018 yaitu kipasan belang (Rhipidura javanica) yang termasuk dalam family Rhipiduridae. Dengan menimbang Peraturan Pemerintah RI No. 7 tahun 1999 pada pasal 4, jenis tumbuhan dan satwa ditetapkan atas dasar golongan yang dilindungi dan tidak dilindungi, dan pasal 5 dinyatakan bahwa suatu jenis tumbuhan dan satwa yang dilindungi memiliki kriteria diantaranya, mempunyai populasi yang kecil, adanya penurunan yang tajam pada jumlah individu di alam, dan daerah persebaran yang terbatas (endemik). Menurut IUCN redlist (2016), Rhipidura javaniva 
berstatus least concern atau resiko rendah, yang artinya populasi jenis burung ini dapat ditemukan dalam jumlah banyak maupun sedikit tergantung persebaran dan kondisi habitatnya. Burung kipasan belang di Indonesia berstatus dilindungi dapat disebabkan karena adanya penurunan populasi di alam.

Berdasarkan status konservasi IUCN redlist, dari 22 jenis burung yang ditemukan di lokasi penelitian terdapat satu jenis burung yang berstatus vulnerable (rentan), yaitu kerak kerbau (Acridotheres javanicus). Berdasarkan IUCN (International Union for Conservation of Nature) suatu spesies dinyatakan rentan (vulnerable) saat sedang menghadapi resiko kepunahan di alam liar pada waktu dekat. Populasi kerak kerbau terus mengalami penurunan akibat banyaknya perangkap yang kemudian diperdagangkan, serta maraknya penggunana pestisida yang mengancam kehidupan jenis burung ini (BirdLife International, 2016).

Adanya jenis burung yang berstatus dilindungi dan rentan tersebut maka diperlukan adanya upaya konservasi seperti perlindungan dan pelestarian untuk menjaga populasi burung tetap stabil. Keberadaan jenis burung di Indonesia, termasuk di Yogyakarta harus dipertahankan. Perkembangan wilayah perkotaan perlu diseimbangi dengan penataan dan pembangunan lanskap perkotaan yang berwawasan lingkungan agar tidak mengganggu keseimbangan laingkungan, salah satunya dengan menyediakan ruang terbuka hijau (Wahyuni dkk, 2018). Adanya RTH berpotensi menjadi habitat bervegetasi bagi para hewan terutama burung-burung. RTH secara tidak langsung menjadi habitat pendukung dalam pelestarian bagi burung-burung.

3. Komposisi Jenis Burung Berdasarkan Tipe Pakan

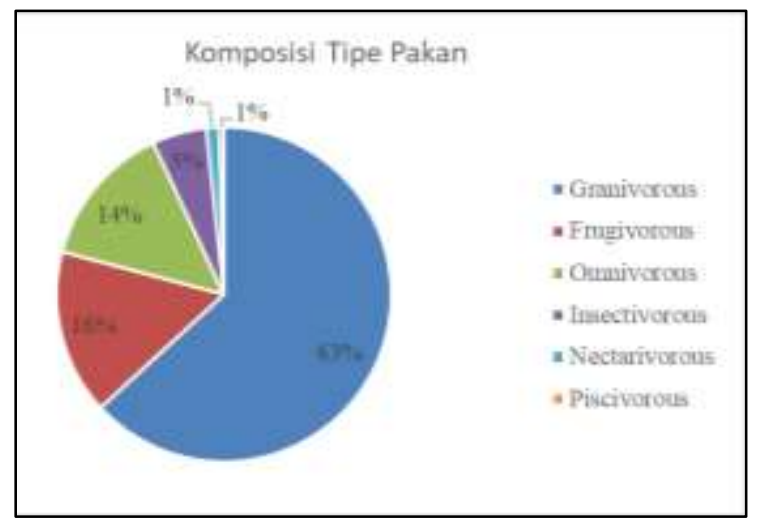

Gambar 2. Komposisi jenis burung berdasarkan tipe pakan pada RTH Royal Ambarrukmo, Sheraton Mustika dan tepian properti Hyatt Regency Yogyakarta.

Berdasarkan Gambar 2. Komposisi jenis burung berdasarkan tipe pakan yang terdapat pada ketiga lokasi penelitian didominasi oleh jenis burung Granivorous, yaitu sebesar 63\%, dengan indeks nilai penting tertinggi yaitu pada burung gereja-erasia. Indeks nilai penting menunjukkan seberapa pentingnya peranan jenis burung tersebut dalam ekosistemnya. Nilai INP yang semakin tinggi menunjukkan bahwa suatu jenis burung tersebut juga semakin bernilai tinggi, dan semakin mempengaruhi kestabilan ekosistem tersebut (Fachrul, 2007). Terdapat tujuh jenis burung pemakan biji yang teramati di ketiga lokasi penelitian dengan komposisi sebesar $63 \%$ dari total jenis burung. Tingginya komposisi pakan jenis burung pemakan biji menunjukkan bahwa ketiga lokasi penelitian 
tersedia sumber pakan berupa biji-bijian yang cukup melimpah. RTH pada hotel Royal Ambarrukmo, Sheraton Mustika dan tepian properti Hyatt Regency merupakan area terbuka yang ditumbuhi oleh berbagai jenis tumbuh-tumbuhan, salah satunya tumbuhan berbiji dan berbulir yang disukai burung jenis granivorous sebagai tempat untuk mencari pakan. Beberapa jenis burung granivorous juga memanfaatkan vegetasi yang ada di lokasi sebagai tempat untuk bertengger bahkan bersarang. Beberapa jenis burung pemakan biji juga dikenal lebih adaptif terhadap kawasan urban seperti pada burung gereja-erasia dan pada jenis burung-burung bondol. Burung jenis frugivorous memiliki komposisi pakan tertinggi ke-dua (16\%). Terdapat tiga spesies burung frugivorous dengan jumlah yang cukup banyak. RTH di ketiga lokasi penelitian banyak ditumbuhi oleh tumbuhan berbuah yang menghasilkan sumber pakan bagi burung jenis ini. Burung frugivorous berperan besar dalam ekosistem untuk membantu menyebar biji dan membantu perkecambahan melalui proses menelan dan memuntahkan benih yang dilakukannya (Dlamini et al., 2018).

4. Vegetasi Penyusun Habitat di RTH Royal Ambarrukmo, Sheraton Mustika dan tepian properti Hyatt Regency Yoyakarta

Tabel 2. Jenis-jenis tumbuhan yang ada di RTH Royal Ambarrukmo, Sheraton Mustika dan tepian properti Hyatt Regency Yogyakarta.

\begin{tabular}{|c|c|c|c|c|c|c|}
\hline \multirow{2}{*}{ No. } & \multicolumn{3}{|c|}{ Jenis Pohon } & \multicolumn{3}{|c|}{ Keberadaan } \\
\hline & Nama lokal & Nama Ilmiah & Famili & $\mathbf{R A}$ & SM & HR \\
\hline 1. & Mangga & Mangifera indica & \multirow{2}{*}{ Anacardiaceae } & $\sqrt{ }$ & $\sqrt{ }$ & - \\
\hline 2. & Kuweni & Mangifera odorata & & $\sqrt{ }$ & - & - \\
\hline 3. & Kenari & Canarium ovatum & Burseracae & - & $\sqrt{ }$ & - \\
\hline 4. & Mindi & Melia azedarach & Meliaceae & $\sqrt{ }$ & - & - \\
\hline 5. & Kelengkeng & Dimocarpus longan & \multirow{3}{*}{ Sapindaceae } & $\sqrt{ }$ & - & - \\
\hline 6. & Kerai payung & Filicium decipiens & & - & $\sqrt{ }$ & - \\
\hline 7. & Matoa & Pometia pinnata & & $\sqrt{ }$ & - & - \\
\hline 8. & Kemuning & Murraya paniculata & Rutaceae & $\sqrt{ }$ & - & - \\
\hline 9. & Glodokan tiang india & Polyalthia longifolia & Annonaceae & - & - & $\sqrt{ }$ \\
\hline 10. & Kantil & Magnolia champaca & Magnoliaceae & $\sqrt{ }$ & - & - \\
\hline 11. & Kamboja merah & Plumeria rubra & \multirow{5}{*}{ Apocynaceae } & $\sqrt{ }$ & $\sqrt{ }$ & - \\
\hline 12. & Kamboja pink & Plumeria sp. & & $\sqrt{ }$ & - & - \\
\hline 13. & Pulai & Alstonia scholaris & & $\sqrt{ }$ & - & - \\
\hline 14. & Bintaro & Cerbera manghas & & $\sqrt{ }$ & $\sqrt{ }$ & - \\
\hline 15. & Damar & Agathis dammara & & $\sqrt{ }$ & - & - \\
\hline 16. & Kelapa & Cocos nucifera & \multirow{4}{*}{ Arecaceae } & - & $\sqrt{ }$ & $\sqrt{ }$ \\
\hline 17. & Palm sadeng & Trachycarpus fortunei & & $\sqrt{ }$ & $\sqrt{ }$ & - \\
\hline 18. & Palm kipas & Livistona rotundifolia & & $\sqrt{ }$ & $\sqrt{ }$ & - \\
\hline 19. & Palm kuning & Dypsis lutescens & & - & $\sqrt{ }$ & $\sqrt{ }$ \\
\hline
\end{tabular}


Biotropic Tahun 2020, Vol.4 (N0. 2): 119 - 133

Penggunaan Ruang Terbuka Hijau di Hotel Bintang Lima di Yogyakarta Sebagai Habitat Burung

\begin{tabular}{|c|c|c|c|c|c|c|}
\hline \multirow{2}{*}{ No. } & \multicolumn{3}{|c|}{ Jenis Pohon } & \multicolumn{3}{|c|}{ Keberadaan } \\
\hline & Nama lokal & Nama Ilmiah & Famili & RA & SM & HR \\
\hline 20. & Palm Putri & Veitchia merilii & & - & $\sqrt{ }$ & - \\
\hline 21. & Variegata & Dracaena reflexa & Asparagaceae & $\sqrt{ }$ & - & - \\
\hline 22 & Kecrutan & Spathodea campanulata & & $\sqrt{ }$ & $\sqrt{ }$ & $\sqrt{ }$ \\
\hline 23. & Kunto bimo & Kigelia africana & Bignoniaceae & $\sqrt{ }$ & $\sqrt{ }$ & - \\
\hline 24. & Tabebuya & Tabebuia heterophyllla & & - & $\sqrt{ }$ & - \\
\hline 25. & Jati & Tectona grandis & Lamiaceae & $\sqrt{ }$ & - & - \\
\hline 26. & Nyamplung & Calophyllum inophyllum & Calophyllaceae & - & $\sqrt{ }$ & - \\
\hline 27. & Mundu & Garcinia dulcis & Clusiaceae & $\sqrt{ }$ & - & - \\
\hline 28. & Cemara udang & Casuarina equisetifolia & Casuarinaceae & $\sqrt{ }$ & - & - \\
\hline 29. & Ketapang & Terminalia catappa & Combretaceae & $\sqrt{ }$ & $\sqrt{ }$ & - \\
\hline 30. & Bungur & Lagerstroemia indica & Lythracea & $\sqrt{ }$ & - & - \\
\hline 31. & Gowok & Syzygium cumini & & $\sqrt{ }$ & - & - \\
\hline 32. & Jambu air & Syzygium aqueum & & $\sqrt{ }$ & - & - \\
\hline 33. & Jambu jamaika & Syzygium malaccense & Myrtaceae & $\sqrt{ }$ & - & - \\
\hline 34. & Jambu wangi & Syzygium jambos & & $\sqrt{ }$ & - & - \\
\hline 35. & Salam & Syzigium polianthum & & $\sqrt{ }$ & - & - \\
\hline 36. & Bisbul & Diospyros blancoi & Ebenacae & $\sqrt{ }$ & - & - \\
\hline 37. & Keben & Barringtonia asiatica & Lecythidaceae & $\sqrt{ }$ & - & - \\
\hline 38. & Sawo kecik & Manilkara kauki & Sapotaceae & $\sqrt{ }$ & - & - \\
\hline 39. & Flamboyan & Delonix regia & & - & $\sqrt{ }$ & - \\
\hline 40. & Bunga kupu-kupu & Bauhinia purpurea & Fabaceae & - & $\sqrt{ }$ & - \\
\hline 41. & Angsana & Pterocarpus indicus & & - & $\sqrt{ }$ & - \\
\hline 42. & Biola cantic & Ficus lyrata & & $\sqrt{ }$ & $\sqrt{ }$ & - \\
\hline 43. & Beringin & Ficus benjamina & & $\sqrt{ }$ & - & $\sqrt{ }$ \\
\hline 44. & Kalpataru & Ficus religiosa & Moraceae & $\sqrt{ }$ & - & - \\
\hline 45. & Karet kebo & Ficus elastica & & - & $\sqrt{ }$ & - \\
\hline 46. & Sukun & Artocarpus altilis & & - & $\sqrt{ }$ & - \\
\hline 47. & Kelor & Moringa oleifera & Moringaceae & $\sqrt{ }$ & - & - \\
\hline 48. & Bugenvil & $\begin{array}{l}\text { Bougainvillea } \\
\text { spectabilis }\end{array}$ & Nyctaginaceae & - & $\sqrt{ }$ & - \\
\hline 49. & Kol banda & Pisonia grandis & & $\sqrt{ }$ & - & - \\
\hline 50. & Melati & Jasminum sp. & Oleaceae & $\sqrt{ }$ & - & - \\
\hline 51. & Blimbing & Averhhoa carambola & & $\sqrt{ }$ & - & - \\
\hline 52. & Blimbing wuluh & Averrhoa bilimbi & Oxalidaceae & $\sqrt{ }$ & $\sqrt{ }$ & - \\
\hline 53. & Pinus & Pinus merkusii & Pinaceae & - & $\sqrt{ }$ & - \\
\hline 54. & Cabe puyang & Piper retrofactum & Piperaceae & $\sqrt{ }$ & - & - \\
\hline 55. & Bambu & Gigantochloa sp. & & - & $\sqrt{ }$ & - \\
\hline 56. & Bambu payung & Fargesia murielae & Poaceae & - & - & $\sqrt{ }$ \\
\hline 57. & Anggur laut & Coccoloba uvifera & Polygonaceae & - & $\sqrt{ }$ & - \\
\hline 58. & Nusa Indah & Mussaenda sp. & Rubiaceae & - & $\sqrt{ }$ & - \\
\hline 59. & Bunga lampion & Physalis alkekengi & Solanaceae & $\sqrt{ }$ & - & - \\
\hline
\end{tabular}

Keterangan : RA (RTH Royal Ambarrukmo), SM (RTH Sheraton Mustika), HR (RTH tepian properti Hyatt Regency Yogyakarta). 
Berdasarkan tabel 2, terdapat sebanyak 59 spesies dari 33 famili jenis tumbuhan yang ditemukan di ketiga RTH Hotel Bintang Lima di Yogyakarta. Jenis tumbuhan yang paling sering dijumpai adalah jenis palempaleman seperti pohon kelapa dan palm kuning. Beberapa jenis bambu hias dan pohon pinus juga sering dijumpai, umumnya berada pada bagian tepi hotel sebagai pembatas.

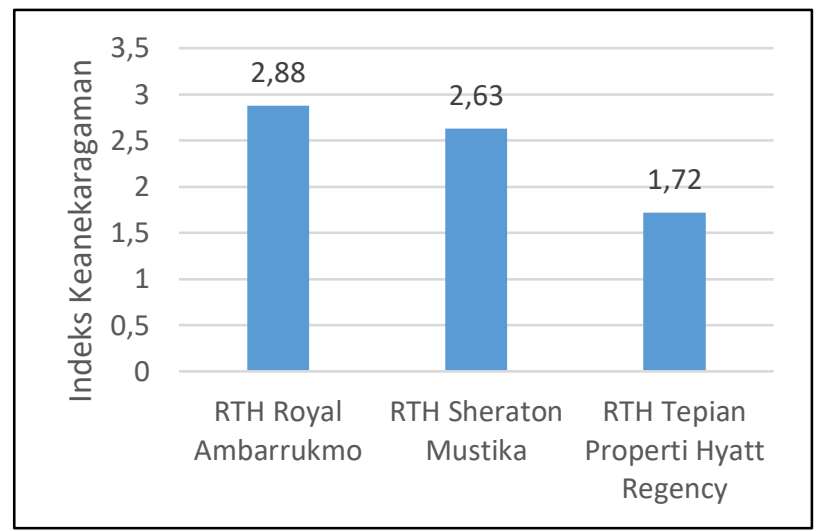

Gambar 3. Indeks Keanekaragaman Jenis Tumbuhan yang ada di RTH Royal Ambarrukmo, RTH Sheraton Mustika, dan RTH tepian properti Hyatt Regency, Yogyakarta.

Berdasarkan gambar 3, RTH Hotel Royal Ambarrukmo memiliki indeks keragaman jenis tumbuhan tertinggi $\left(H^{\prime}>2,0\right)$. Semakin besar nilai indeks, maka semakin beragam pula jenis tumbuhan didalamnya. Nilai indeks keanekaragaman jenis tumbuhan yang dihasilkan, berbanding lurus dengan indeks keanekaragaman jenis burung yang ditemukan di lokasi penelitian (Gambar 1). Hal tersebut mengindikasikan bahwa keanekaragaman jenis tumbuhan disuatu habitat mempengaruhi keanekaragaman jenis burung yang hidup didalamnya. Tingginya tingkat keragaman jenis tumbuhan, akan memberikan preferensi sumber pakan maupun tempat berlindung yang lebih banyak bagi berbagai jenis burung, sehingga keragaman jenis burung di kawasan tersbut pun juga akan meningkat. Burung-burung yang dijumpai di ketiga kawasan, menggunakan vegetasi penyusun RTH sebagai penunjang kehidupannya, diantaranya untuk mencari makan, bertengger dan bersarang. Indeks keanekaragaman tumbuhan pada tepian Hyatt Regency Yogyakarta, termasuk dalam tingkatan sedang. Hal tersebut disebabkan karena penelitian yang dilakukan hanyalah berada di tepian property Hyatt Regency, tepatnya di sepanjang jalan Palagan Tentara Pelajar. Indeks keanekaragaman tentunya akan memperoleh hasil yang berbeda apabila penelitian dilakukan langsung dibagian dalam hotel. Lokasi penelitian yang terbatas tersebut, dihasilkan jenis vegetasi yang terbatas pula. Vegetasi yang ditemui diantaranya merupakan pohon peneduh jalan seperti kecrutan dan beringin. Jenis tumbuhan yang rendah tersebut mempengarui pula keanekaragaman burung yang ditemui.

5. Penggunaan Ruang Terbuka Hijau di Hotel Berbintang Lima di Yogyakarta Sebagai Habitat Burung

Penggunaan RTH di ketiga hotel berbintang lima sebagai habitat burung diketahui berdasarkan aktivitas burung yang dijumpai meliputi kegiatan mencari makan, bertengger dan bersarang. Beberapa jenis burung yang dijumpai, terlihat sedang melakukan aktivitas mencari makan. Jenis 
burung tersebut sebagian besar merupakan jenis burung granivorous. Burung pemakan biji dikenal lebih adaptif terhadap kawasan urban sehingga burung jenis ini mudah dijumpai dihabitat manapun. Mereka mencari makan diatas permukaan tanah untuk mendapatkan biji-bijian baik dari bulir rumput, buah-buahan kering yang dihasilkan oleh tumbuhan pinus (Pinus merkusii) dan palem-paleman seperti pohon kelapa (Cocos nucifera), palm kuning (Dypsis lutescens), palm kipas (Livistona rotundifolia) dan palm putri (Veitchia merilii). Jenis-jenis burung tersebut diantaranya bondol jawa, burung gerejaerasia, bondol haji dan burung perkutut.

Ketiga lokasi RTH menyediakan sumber pakan bagi burung-burung yang hidup di dalamnya, melalui komponen penyusun vegetasi didalamnya. Tumbuhan bukan hanya berperan sebagai substrat untuk mencari makan, tetapi juga berperan sebagai penyedia makanan bagi para avifauna (Gomes et al., 20008). Terdapatnya burung jenis frugivorous, omnivorous dan insectivorous yang juga ditemukan di lokasi penelitian, dapat mengindikasikan adanya sumber pakan yang melimpah. Diketahui bahwa ketiga lokasi penelitian ditumbuhi oleh berbagai jenis tumbuhan yang berpotensi menjadi sumber makanan bagi para burung, seperti pohon yang termasuk dalam keluarga Moraceae dan Arecacaeae. Selain itu tumbuhan juga menjadi tempat tinggal bagi bermacam serangga yang juga merupakan sumber pakan bagi burungburung berjenis insectivorous. RTH menciptakan suatu ekosistem yang stabil melalui terbentuknya jejaring makanan, dengan vegetasi didalamnya berperan sebagai produsen.

Sebagian besar jenis burung yang ditemukan di lokasi penelitian, terlihat sedang melakukan aktivitas bertengger di pepohonan. Beberapa jenis burung terlihat bertengger di pepohonan dalam koloni (seperti pada jalak cina dan burung punai gading), bertengger secara berpasangan, maupun bertengger sendirian. Aktivitas burung saat bertengger dilakukan untuk hanya sekedar istirahat, tidur atau mengamati mangsa. Beberapa burung yang ditemukan hanya bertengger untuk singgah sementara (cekakak sungai), dan beberapa jenis selalu datang untuk bertengger secara kontinyu (jalak cina saat bulan migrasi, jalak kerbau dan punai). Beberapa burung bertengger baik di cabang pepohonan maupun di semak. Kegiatan bertengger pada burung merupakan periode inaktif pada burung, analog dengan aktivitas tidur pada manusia. Pemilihan tempat bertengger pada burung umumnya dipengaruhi oleh preferensi setiap jenis atas keberadaan sumber makanan dan air (Jayson, 2018). Atas uraian tersebut maka RTH diketiga lokasi hotel berbintang lima, menyediakan tempat bagi para burung untuk dapat melakukan aktivitas bertengger melalui pepohonan yang tumbuh didalamnya.

RTH di ketiga lokasi penelitian juga digunakan oleh beberapa jenis burung untuk bersarang, seperti pada bondol haji yang membuat sarangnya di Dracaena reflexa dan 
burung kutilang yang membangun sarangnya di Spathodea campanulata. Pada kebanyakan spesies, pemilihan situs bersarang dalam habitat tertentu merupakan salah satu penentu utama keberhasilan dalam proses breeding. Menurut Acharja (2019), terdapat beberapa faktor yang menentukan pemilihan lokasi bersarang bagi burung, yaitu, ketersediaan makanan bagi induk dan anaknya, keberadaan predator, ketersediaan material penyusun sarang, dan keberadaan iklim yang sesuai untuk membesarkan anakanaknya.

Ditemukannya sarang dari berbagai jenis burung yang dibangun di pepohonan yang terdapat di ketiga lokasi penelitian, menandakan terjadinya siklus breeding di lokasi tersebut. Hal itu mengindikasikan bahwa RTH di ketiga hotel berbintang lima, merupakan habitat yang mampu mendukung siklus kehidupan bagi beberapa jenis burung. Komponen vegetasi penyusun didalamnya mampu memberikan perlindungan dan mampu menyediakan sumber pakan dan material sarang bagi induk untuk dapat membesarkan anak-anaknya.

Aktivitas lain yang dilakukan oleh burung yang dijumpai di RTH hotel berbintang lima yaitu, mandi, berjemur, bersolek (preening), dan menarik lawan jenis (courtship). Banyaknya aktivitas yang dilakukan berbagai jenis burung, menunjukkan bahwa RTH di hotel berbintang lima menjadi habitat yang ideal bagi para burung, khususnya burung yang mudah beradaptasi pada daerah urban, seperti kelompok burung bondol. Kota Yogyakarta sebagai salah satu kota yang mengalami pertumbuhan dan perkembangan yang pesat diharapkan dapat mengutamakan pembangunan selalu terencana, dengan pengalokasian lahan untuk ruang terbuka hijau. Adanya RTH yang dibangun oleh hotel berbintang lima memiliki nilai ekologis yang sangat penting dalam menjaga keseimbangan lingkungan. Secara tidak langsung, RTH ikut berperan dalam mendukung pelestarian vegetasi dan satwa yang ada didalamnya.

\section{KESIMPULAN}

Penggunaan RTH di Royal Ambarrukmo Hotel, Sheraton Mustika Yogyakarta Resort \& Spa dan tepian properti Hyatt Regency Yogyakarta berperan sebagai habitat yang ideal bagi beberapa jenis burung. Hal tersebut dapat dilihat melalui banyaknya aktivitas burung yang dilakukan dalam kawasan tersebut, seperti mencari makan, bertengger, bersarang, mandi, berjemur, bersolek dan courtship. Semakin tinggi keragaman jenis vegetasi yang menyusun suatu habitat akan berpengaruh positif terhadap keanekaragaman jenis burung yang berada didalamnya. Kota Yogyakarta sebagai salah satu kota yang mengalami pertumbuhan dan perkembangan yang pesat, diharapkan dapat mengutamakan pembangunan terencana, dengan pengalokasian lahan untuk RTH. Adanya RTH yang dibangun oleh hotel berbintang lima memiliki nilai ekologis yang sangat penting dalam menjaga keseimbangan 
lingkungan. Secara tidak langsung, RTH pada hotel berbintang lima di Yogyakarta ikut berperan dalam mendukung pelestarian vegetasi dan jenis burung yang berada didalamnya.

\section{DAFTAR PUSTAKA}

Acharja, I.P. 2019. Evaluation of nest habitat, site preferences and architecture of the critically endangers White-bellies Heron Ardea insign in Bhutan. Bird Conservation International. 1-19.

BirdLife International. 2016. Rhipidura javanica. Didownload pada 20 Juni 2020. The IUCN Red List of Threatened Species

2016:e.T103709500A94090845.https:/ /dx.doi.org/10.2305/IUCN.UK.20163.R LTS.T103709500A94090845.en.

Bonier, F., Martin, PR., and JC. Wingfield. 2007. Urban Birds Have Broader Environmental Tolerance. Biology Letters. 3: 670-673.

Campos, DP., Laith, AB., Aiiz, R, and TB. Daniel. 2009. Perch Exposure and Predation Risk: A Comparative in Passerines. Acta Ethologica. 12:93-98.

Cartwright, LA., Taylor DR., Wilson, DR., and P. Chow-Frase. 2014. Urban Noise Affects song Structure and Daily Patterns of Song Production in Red-Winged lackbirds (Agelaius phoenicus). Urban Ecosystem. 17(2):561-572.

Catchpole, CK, and PJB. Slater. 2003. Bird Song: Biological Themes and Variation. Cambridge University Press, Cambridge.

Croci, S., Butet, A., and P. Clergeau. 2008. Does Urbanization Filter Birds On The Basis of Their Biological Traits?. Condor. 18:299-321.

Dlamini, P., Zachariades, C., and CT. Downs. 2018. The effect of frugivorous birds on seed dispersal and ermination of the invasive brazilian pepper tree (Schinus terebinthifolius) asnd Indian laurel (Litsea glutinosa). South Africa Journal of Botany. 114:61-68.

Estrada, A., Coates-Estrada, R., and DA. MerittJr. 1997. Anthropogenic landscape changes and avian diversity at Los Tuxtlas, Mexico. Biodiversity and Conservation. 6:19-43.

Fachrul, MF. 2007. Metode Sampling Bioekologi. Bumi Aksara,Jakarta.

Gabbe, AP., Robinson, SK., and JD. Brawn. 2002. Tree-species preferences of foraging insectivorous birds: implications for floodplain forest restoration. Conservation Biology. 16(2):462-470.

Gomes, VSM., Loiselle, BA., and MAS. Alves. 2008. Birds Foraging for Fruits and Insects in Shrubby Restinga Vegetation, Southeastern Brazil. Biota Neotropica. $8(4): 21-28$.

Halfwerk, W., Holleman, LJM., Lessels, CM., and H. Slabbekorn. 2011. Negative Impact of Traffic Noise on Avian Reproductive Succes. Journal of Applied Ecology. 48(1):210-219.

Harvey, CA., Medina, A., Sánchez, DM., Vílchez, S., Hernández, B., Saenz, JC., Maes, JM., Casanoves, F. , and FL. Sinclair. 2006. Patterns of animal diversity indifferent forms of tree cover in agricultural landscapes. Ecological Applications. 16(5):1986-1999.

Hu, Y., and GC. Cardoso. 2009. Are Bird Species That Vocalize at Higher Frequencies Preadapted to Inhabit Noisy Urban Area?. Behavioral Ecology. 20:12681273.

Jayson, EA. 2018. Factors Affecting Roosting Ecology of Birds in Kerala. Kerala Forest Research Institute, Peechi, Kerala. pp. 45.

Luck, GW., and GC. Daily. 2003. Tropical countryside birdassemblages: Richness, composition and foraging differ by 
Biotropic Tahun 2020, Vol.4 (NO. 2): 119 - 133

Penggunaan Ruang Terbuka Hijau di Hotel Bintang Lima di Yogyakarta Sebagai Habitat Burung

landscape context. Ecological Applications. 13:235-247.

Marzluff, JM., Gehlbach, FR., and DA. Manuwal. 1998. Urban environments: influences on avifauna and challenges for the avian conservationist. Island Press, Washington, D.C. pp.283-296.

Menteri Lingkungan Hidup Dan Kehutanan Republik Indonesia. Peraturan Menteri Lingkungan Hidup Dan Kehutanan Republik Indonesia Nomor P.106/Menlhk/Setjen/Kum.1/12018

Tentang Jenis Tumbuhan Dan Satwa Yang Dilindungi. Berita Negara Republik Indonesia Tahun 2019 Nomor 32, Jakarta.

Ratnasari, A., Sitorus, SRP., dan B. Tjahjono. 2015. Perencanaan Kota Hijau Yogyakarta Berdasarkan Penggunaan Lahan Dan Kecukupan RTH. Tata Loka. 17(4):196-208.

Republik Indonesia. 1999. Peraturan Pemerintah No. 7 Tahun 1999 tentang Pengawetan Jenis Tumbuhan dan Satwa. Lembaraan Negara RI Tahun 1999. Sekretariat Negara, Jakarta.

Republik Indonesia. 2007. Undang-Undang Republik Indonesia No. 26 Tahun 2007 tentang Penataan Ruang. Lembaraan Negara RI Tahun 2007. Sekretariat Negara, Jakarta.

Rodewald, A., and M. Abrams. 2002. Floristics and avian community structure: implications for regional changes in eastern forest composition. Journal of Forest Science. 48:267-272.

Salek, M., Svobodova, J., and P. Zasadil, P. 2010. Edge effect of low-traffic forest roads on bird communities in secondary production forests in central Europe. Landscape Ecology. 25(7):1113-1124.

Schaefer, V. 1994. Urban biodiversity: Biodiversity in British Columbia. Environment Canada, Canadian
Wildlife Service. Vancouver, British Columbia, Canada. pp. 307-318.

Sharma, RC., Dinesh, B., and RK. Sharma. 2004. Breeding Succes of Tropical Spotted Munia Lonchura punctulata In Urbanized And Forest Habitats. Ornithological Science. 3:113-117.

Silva, JMC., Uhl, C., and G. Murray. 1996. PlantSuccession, Landscape Management, and the Ecology of Frugivorous Birds in Abandoned Amazonian Pastures. Conservation Biology. 10(2):491-503.

Soegianto, A. 1994. Ekologi Kuantitatif. Penerbit Usaha Nasional, Surabaya.

Tobolka, M. 2011. Roosting of Tree Sparrow (Passer montanus) and HouseSparrow (Passer domesticus) in White Stork (Ciconia ciconia) Nests During Winter. Tubitak. 35(6):879-882.

Wahyuni, S., Syartinilia, dan YA. Mulyani. 2018. Efektivitas Ruang Terbuka Hijau Sebagai Habitat Burung di Kota Bogor dan Sekitarnya. Jurnal Lanskap Indonesia. 10(1):29-36. 